\title{
PENGARUH MODEL PEMBELAJARAN KOOPERATIF TIPE GROUP INVESTIGATION TERHADAP HASIL BELAJAR SISWA
}

\author{
Nasuha \\ Sekolah Tinggi Agama Islam ( STAI) Darud dakwah Wal-Isyad (DDI) Kota Makassar, \\ Indonesia \\ Email : nasuha2801@gmail.com
}

\section{PEMBAHASAN}

\section{A. Pengertian Model Pembelajaran Kooperatif}

Model pembelajaran kooperatif adalah model pembelajaran yang mengutamakan eksistensi kelompok. Model pembelajaran kooperatif mengutamakan kolaborasi dalam memecahkan masalah untuk menerapkan pengetahuan dan keterampilan untuk mencapai tujuan pembelajaran ${ }^{1}$.

\section{B. Unsur unsur Pembelajaran Kooperatif}

Didalam pembelajaran kooperatif siswa belajar bersama dalam kelompok-kelompok kecil yang saling membantu satu sama lain. Kelas disusun dalam kelompok yang terdiri dari 4 atau 6 orang siswa, dengan kemampuan yang heterogen. Maksud kelompok heterogen adalah terdiri dari campuran kemampuan siswa, jenis kelamin, dan suku. Hal ini bermanfaat untuk melatih siswa menerima perbedaan dan bekerja dengan teman yang berbeda latar belakangnya ${ }^{2}$.

Pada pembelajaran kooperatif diajarkan keterampilan-keterampilan khusus agar dapat bekerja sama dengan baik di dalam kelompoknya, seperti menjadi pendengar yang baik, siswa diberi lembar kegiatan yang berisi pertanyaan atau tugas yang direncanakan untuk diajarkan. Selama kerja kelompok, tugas anggota kelompok adalah mencapai ketuntasan ${ }^{3}$.

${ }^{1}$ Sudarsana, I. K. (2016). PEMIKIRAN TOKOH PENDIDIKAN DALAM BUKU LIFELONG LEARNING:POLICIES, PRACTICES, AND PROGRAMS (Perspektif Peningkatan Mutu Pendidikan di Indonesia). Jurnal Penjaminan Mutu, (2016), 44-53.

${ }^{2}$ Sudarsana, I. K. (2015). PENINGKATANMUTU PENDIDIKAN LUAR SEKOLAH DALAM UPAYA PEMBANGUNAN SUMBER DAYA MANUSIA. Jurnal Penjaminan Mutu,(Volume 1 Nomor 1 Pebruari 2015), 1-14.

${ }^{3}$ Wisarja, I. K., \& Sudarsana, I. K. (2017).Praksis Pendidikan Menurut Habermas (Rekonstruksi Teori Evolusi Sosial Melalui Proses Belajar Masyarakat). IndonesianJournal of Educational Research, 2(1),18-26. 


\section{Pengaruh Model Pembelajaran Kooperatif Tipe Group Investigation Terhadap Hasil Belajar Kognitif Siswa}

Kegiatan guru yang berorientasi pembelajaran konvensional,yaitu :

Pertama, guru menyampaikan atau mentransfer ilmu pengetahuan dan umumnya mengharapkan siswa mengidentifikasi, meniru informasi yang disampaikan. Ketika terjadi diskusi dalam kelas, umumnya dipimpin oleh guru.

Kedua, guru hanya menyajikan informasi yang ada dibuku atau teks. informasi tersebut disampaikan secara langsung, menyediakan hanya sebuah penampakan dari suatu peristiwa yangkompleks, dan sebuah kebenaran.

Ketiga, ketika sebuah pembelajaran dirancang ke dalam sebuah setting kelas kooperatif, pelaksanaannya tidak sepenuhnya kooperatif dan mewajibkan siswa untuk bekerja dalam sebuah kelompok kecil dalam menyelesaikan soal yang diyakini.

Keempat, guru jarang memperhatikan proses siswa dalam menyelesaikan masalah. Ketika siswa diharapkan pada sebuah permasalahan, guru jarang menilai bagaimana cara atau pola pikir siswa dalam menyelesaikan permasalahan dan yang menjadi prioritas adalah kebenaran jawaban yang diungkapkan siswa.

Dalam proses pembelajaran dengan model pembelajaran GI terjadi peningkatan kemampuan dalam melakukan analisis dan sintesis terhadap segala informasi sehingga penguasaan akan materi pelajaran lebih baik. Dengan melihat proses belajar seperti itu maka siswa dapat membangun sendiri pengetahuannya dan secara langsung menggunakan pengetahuannya untuk membahas permasalahan yang diangkat, sehingga pembelajaran menjadi sangat bermakna. Disamping itu, kegiatan pembelajaran dengan model pembelajaran GI dapat meningkatkan keterampilan sosial dan kemampuan akademis siswa. Dengan meningkatnya keterampilan sosial akan memicu terjadinya komunikasi yang lebih baik antar anggota kelompok, akibatnya terjadi pertukaran pengetahuan yang sangat baik yang pada akhirnya dapat meningkatkan penguasaan materi yang sedang dipelajari ${ }^{4}$.

\section{Pengaruh Model Pembelajaran Kooperatif Tipe Group Investigation Terhadap Hasil Belajar Afektif Siswa}

Secara teoritik model pembelajaran GI efektif untuk menarik minat siswa terhadap pelajaran pelajaran agama. Siswa tidak lagi memandang bahwa pelajaran pelajaran agama

\footnotetext{
${ }^{4}$ Anas dan Sudijono. 2007. Evaluasi Pendidikan. Jakarta : PT Raja Grafindo Persada.
} 
merupakan pelajaran hafalan melainkan pelajaran yang dapat menanamkan sikap-sikap atau nilai yang harus dimiliki oleh seorang siswa yakni, 1) Skeptis, yaitu sikap tidak mudah percaya, yang merupakan dasar dari inkuiri. Sikap ini ditunjukan selalu bertanya dan ingin mendapat jawaban, 2) Kuriosity, adalah sikap ingin tahu sebagai implikasi dari sikap skeptis, 3) respek dalam menggunakan rasionalisasi, merupakan sikap yang selalu mendahulukan pelaksanaan rasional investigasi dalam belajar, 4) respek terhadap faktafakta atau data untuk menunjukan kebenaran, 5) objektif, adalah sikap yang selalu menjunjung kebenaran, 6)mau menunda pendapat, merupakan sikap yang tidak segera memberikan keputusan sebelum terkumpul data atau informasi yang cukup, 7) toleransi terhadap perubahan, merupakan sikap mudah menyesuaikan diri terhadap perubahan yang terjadi pada lingkungan 5 .

${ }^{5}$ Sudarsana, I. K. (2018). Pengaruh model pembelajaran kooperatif terhadap peningkatan mutu hasil belajar siswa. Jurnal Penjaminan Mutu, 4(1), 20-31. 


\section{DAFTAR PUSTAKA}

Sudarsana, I. K. (2016). PEMIKIRAN TOKOH PENDIDIKAN DALAM BUKU LIFELONG LEARNING:POLICIES, PRACTICES, AND PROGRAMS (Perspektif Peningkatan Mutu Pendidikan di Indonesia). Jurnal Penjaminan Mutu, (2016), 44-53.

Sudarsana, I. K. (2015). PENINGKATANMUTU PENDIDIKAN LUAR SEKOLAH DALAM UPAYA PEMBANGUNAN SUMBER DAYA MANUSIA. Jurnal Penjaminan Mutu,(Volume 1 Nomor 1 Pebruari 2015), 1-14.

Wisarja, I. K., \& Sudarsana, I. K. (2017).Praksis Pendidikan Menurut Habermas (Rekonstruksi Teori Evolusi Sosial Melalui Proses Belajar Masyarakat). IndonesianJournal of Educational Research, 2(1),18-26.

Anas dan Sudijono. 2007. Evaluasi Pendidikan. Jakarta : PT Raja Grafindo Persada.

Sudarsana, I. K. (2018). Pengaruh model pembelajaran kooperatif terhadap peningkatan mutu hasil belajar siswa. Jurnal Penjaminan Mutu, 4(1), 20-31. 